\title{
固体電解質燃料電池用カソード微構造と電極性能に及ぼす通電処理の影響
}

\author{
佃＼cjkstart洋・山下晃弘・長谷崎和洋 \\ 三菱重工業(株)技術本部長崎研究所, 851-03 長崎県長崎市深堀町 5-717-1
}

\section{Effect of Current-Flow Treatment on the Micrastructure and Polarization Change of Cathode of Solid Oxide Fuel Cells}

\author{
Hiroshi TSUKUDA, Akihiro YAMASHITA and Kazuhiro HASEZAKI \\ Nagasaki Research \& Development Center, Technical Headquarters, Mitsubishi Heavy Industries Ltd., \\ 5-717-1, Fukahori-machi, Nagasaki-shi 851-03
}

\begin{abstract}
In order to study the reaction area of the cathode of solid oxide fuel cells, the changes in microstructure of the cathode with a current-flow treatment were investigated. Cathode samples $\left(\mathrm{La}_{0.9} \mathrm{Sr}_{0.1} \mathrm{MnO}_{3}+10\right.$ mass $\%$ $\mathrm{ZrO}_{2}$ ) with two different microstructures were prepared. Decrease of cathodic polarization by the currentflow treatment was observed. The observations of microstructure change of the cathode suggested that the movement of oxygen ion and vacancy took place at boundary between electrolyte and cathode. The reason of decrease of cathodic polarization by current-flow treatment was discussed.
\end{abstract}

[Received February 28, 1997; Accepted July 4, 1997]

Key-words : SOFC, Cathode, Microstructure, Three phase boundary, Polarization, Current-flow treatment

\section{1. 緒 言}

固体電解質燃料電池は，高効率発電システムとして期待され ており，開発が急速に進められている．固体電解質燃料電池の 変換効率は，電解質と電極の部分で生じる抵抗過電圧と活性化 過電圧ならびに濃度過電圧で決まる内部抵抗に大きく影響され る.このため, 固体電解質燃料電池の実用化には内部抵抗, 特 に電解質と電極の界面部分での酸素の酸化還元反応に関係する 活性化過電生の低減が重要になる. カソードでは, 酸素の還元 反応が 3 相（電解質/電極/気相）界面で生じていると考えら れている11,2)が, 現在のところ十分に検証されているとは言え ない, 反応領域を明らかにすることは, 電極構造の最適化を進 めるうえで重要と考えられる。

本研究では, カソードでの還元反応の生じる領域を検討する ために短時間に電極特性が大きく変化する現象である通電処理 を取り上げた，通電処理による電極特性の変化は，多くの研究 者が指摘している現象である3),4)が, 微構造変化との関係を検 討した例はない.そこで, 通電処理前後の微構造を観察し, 通 電処理が界面部の微構造に及ぼす影響を検討した. 更に, 通電 時のカソードにおける還元反応の生じる領域と通電処理による 電極特性の変化の要因を考察した。

\section{2. 実験方法}

\section{1 原料と成膜条件}

カソード材料は, $\mathrm{La}_{0.9} \mathrm{Sr}_{0.1} \mathrm{MnO}_{3}$ に 10 mass\% の YSZ (8 $\mathrm{mol} \% \mathrm{Y}_{2} \mathrm{O}_{3}$ 安定化 $\mathrm{ZrO}_{2}$ : 平均粒径 $0.2 \mu \mathrm{m}$ ) を添加して用い た。微構造の異なる電極を作るために $\mathrm{La}_{0.9} \mathrm{Sr}_{0.1} \mathrm{MnO}_{3}$ として 平均粒径 $0.2 \mu \mathrm{m}$ と $0.8 \mu \mathrm{m}$ の 2 種類の粉体を使用した. それぞ れの混合粉体から, ドクターブレード法とスクリーンプリント 法によりそれぞれ膜状に成形した。次に, 電解質の YSZ (8 $\mathrm{mol} \% \mathrm{Y}_{2} \mathrm{O}_{3}$ 安定化 $\mathrm{ZrO}_{2}$ ）上に膜状のカソードをはり付けた後

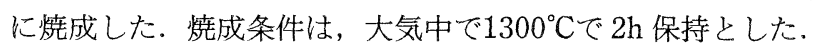

\section{2 電極性能の評価}

焼成後の材料は, Ptペーストを用いて対極と参照極を製膜 し, 更に各電極にPtメッシュとPt 線を用い集電と電流の取 り出しを行った。図 1 に試料の概観図を示す。測定試料を $1000^{\circ} \mathrm{C}$ ま゙昇温したのち，カレントインターラプション法に より電流一電圧特性を評価した，測定の終了後, 温度を $1000^{\circ} \mathrm{C}$ に保ったまま, 電流密度 $0.5 \mathrm{~A} / \mathrm{cm}^{2}$ で電流を $18.5 \mathrm{~h}$ 通電した。 通電処理後引き続きカレントインターラプション法により電流電王特性の測定を再度行った。 また, 得られた電流密度と過電 圧の関係から交換電流密度を推定した5)。

\section{3 微構造の観察}

電極性能評価前後の試料の表面には, 肉眼でははく離等の大 きな損傷は認められなかった。そこで, 試料の微構造の観察を 行った. 通電処理前後の試料を, ダイヤモンドカッターで 5 $\mathrm{mm} \times 5 \mathrm{~mm}$ に切断した後に樹脂埋めし, 最終的に $1 \mu \mathrm{m}$ のダ イヤモンドペーストを用いて研磨した。通電処理前の試料観察 には，電極性能測定試料と同一条件で調製した試料を用いた。

微構造の観察により, カソードと電解質と気相の 3 相界面 量, カソードと電解質の 2 相界面量及び 3 相界面の曲率半径

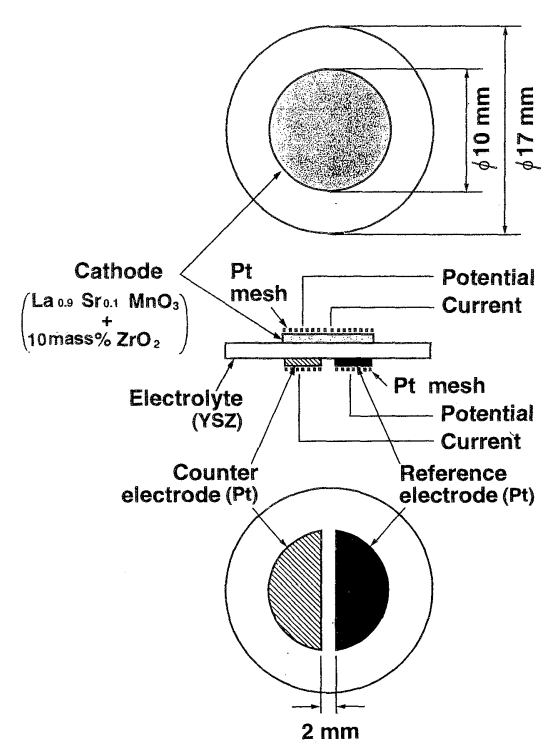

Fig. 1. Appearance of the specimen. 
を計測した。同時に 2 相界面の形状変化を観察した。 3 相界面 量 $\left(L_{\mathrm{A}}\right)$ と 2 相界面量 $\left(A_{\mathrm{A}}\right)$ の算定には以下の式を用いた6).

$$
\begin{aligned}
L_{\mathrm{A}} & =\frac{\pi}{2} \bar{N}_{\mathrm{L}} \\
A_{\mathrm{A}} & =\bar{L}_{\mathrm{L}}
\end{aligned}
$$

$L_{\mathrm{A}}: 3$ 相界面量 $\left(\mu \mathrm{m}^{-1}\right)$

$\bar{N}_{\mathrm{L}}$ : 試料断面の単位長さ当たりの 3 相界面の平均点数 $\left(\mu \mathrm{m}^{-1}\right)$ $A_{\mathrm{A}}: 2$ 相界面量 (一)

$\bar{L}_{\mathrm{L}}$ : 試料断面の単位長さ当たりの 2 相界面の平均長さ (一) 試料断面の観察より直接得られる情報は $N_{\mathrm{L}}$ と $L_{\mathrm{L}}$ であり，本 研究では1000倍に拡大した反射電子像により観察した。観察 点数は 8 視野以上とし，平均值は測定点を正規確率紙上にプ ロットし，存在確率50\%の值を用いた。 また，カソードは $\mathrm{La}_{0.9} \mathrm{Sr}_{0.1} \mathrm{MnO}_{3}$ と YSZ の混合物であるので, 電解質とカソー ドの界面には YSZ 粒同士の界面が存在する。電解質とカソー ド中の YSZ が面接接触している部分は，2相界面や 3 相界面 としての機能はないと考えられる. 後に示す界面部の観察結果 より，カソード中の YSZ 粒子が界面部分に濃縮する傾向は認 められなかった，したがって，真の界面量は測定からの推定值 とカソード中の LSM の体積分率の積と考えられる. しかし, 本研究では通電処理前後の界面量の変化を観察することを目的 としており，これらの補正を行っていない。

3 相（電解質/カソード/気相）界面の曲率半径は，28000倍 に拡大した写真より算出し, 测定点10点以上として平均值を 界面量と同様の方法により求めた. なた, 界面での組成変化を 観察するために，オージェ電子分光分析法により元素分布を調 ベた。

\section{3. 結果と考察}

測定した試料は，カソードの $\mathrm{La}_{0.9} \mathrm{Sr}_{0.1} \mathrm{MnO}_{3}$ の原料粉体の 平均粒径が $0.2 \mu \mathrm{m}$ の試料を Sample A とし， $0.8 \mu \mathrm{m}$ の試料を Sample B とした。

3.1 通電処理による電極性能の変化

両試料の通電処理前後の電流一過電圧特性を図 2 に示す。ま た, 電流一過電圧特性より得られた交換電流密度を表 1 に示 す。通電処理により交換電流密度が， Sample A で約28倍に，

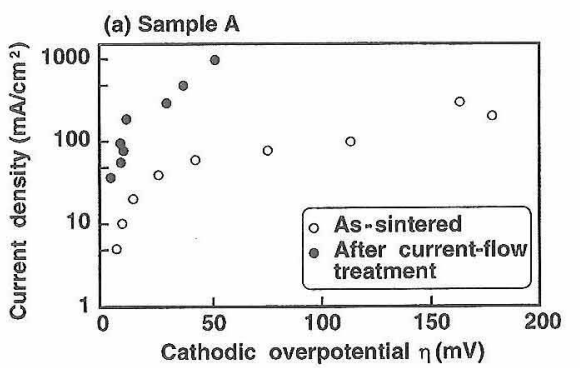

(b) Sample B

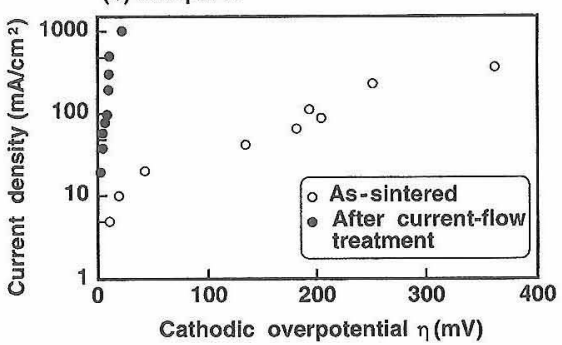

Fig. 2. Cathodic polarization curves for two different cathodes at $1273 \mathrm{~K}$ in air. (a) Sample A, (b) Sample B.
Table 1. Properties of Samples

\begin{tabular}{|c|c|c|c|c|}
\hline & \multicolumn{2}{|c|}{ Sample A } & \multicolumn{2}{c|}{ Sample B } \\
\cline { 2 - 5 } & $\begin{array}{l}\text { As - } \\
\text { sintered }\end{array}$ & $\begin{array}{l}\text { After } \\
\text { ireatment }\end{array}$ & $\begin{array}{l}\text { As- } \\
\text { sintered }\end{array}$ & $\begin{array}{l}\text { After } \\
\text { treaiment }\end{array}$ \\
\hline $\begin{array}{c}\text { Three phase } \\
\text { boundary } \\
\left(\mu \mathrm{m}^{-1)}\right)\end{array}$ & 0.42 & 0.58 & 0.39 & 0.50 \\
\hline $\begin{array}{c}\text { Two phase } \\
\text { boundary } \\
(-)\end{array}$ & 0.23 & 0.29 & 0.13 & 0.39 \\
\hline $\begin{array}{c}\text { Radius of } \\
\text { curvature at } \\
\text { three phase } \\
\text { boundary }\end{array}$ & 0.22 & 0.11 & 0.25 & 0.12 \\
\hline $\begin{array}{c}\text { Exchange } \\
\text { current } \\
\text { density } \\
\left(\mathrm{mA} / \mathrm{cm}^{2}\right)\end{array}$ & 0.9 & 25.1 & 2.4 & 10.1 \\
\hline
\end{tabular}

* Current-fllow treatment at $0.5 \mathrm{~A} / \mathrm{cm}^{2}$ for $18.5 \mathrm{~h}$ (at 1273K)

Sample B で約 4 倍にそれぞれ増大している.

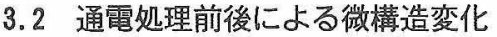

\subsubsection{3 相界面量}

図 3 に示す観察例より， $N_{\mathrm{L}}$ を算出した。両試料の $N_{\mathrm{L}}$ の通 電処理前後の变化を図 4 に示す. $N_{\mathrm{L}}$ の分布はほぼ正規分布則 にしたがっており，通電処理により $N_{\mathrm{L}}$ は大きくなる，得られ た $N_{\mathrm{L}}$ の平均值より，(1) 式を用いて $L_{\mathrm{A}}$ を算出し表 1 にあわ せて示した。この結果, 通電処理により 3 相界面量が Sample A で約 $40 \%$, Sample Bで約30\%それぞれ増大していた。

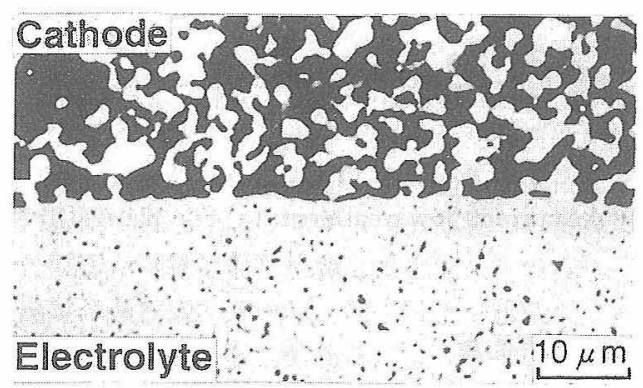

(a) As - sintered

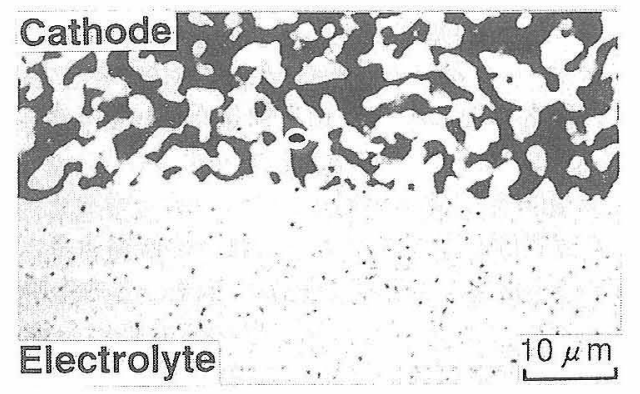

(b) After current-flow treatment

Fig. 3. Backscattered electron images of the Sample B. (a) Assintered, (b) after current-flow treatment. 


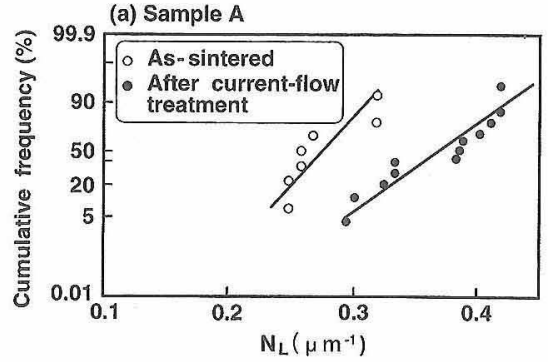

(b) Sample B

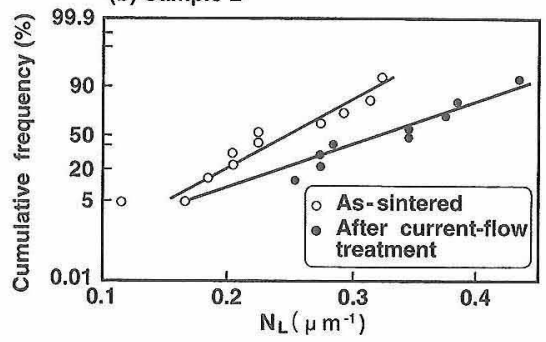

Fig. 4. Changes of the distribution of the three phase boundary length by the current-flow treatment. (a) Sample A, (b) Sample B.
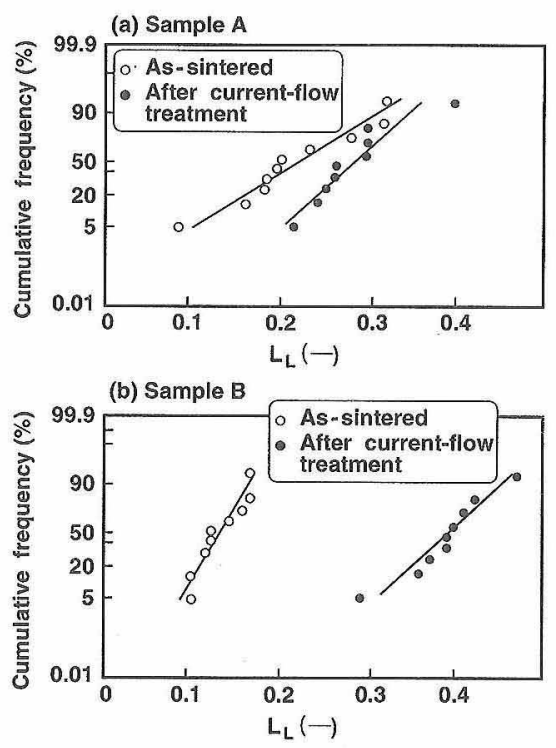

Fig. 5. Changes of the distribution of the two phase boundary length by the current-flow treatment. (a) Sample A, (b) Sample B.

\section{2 .22 相界面量}

2 相界面量も 3 相界面量と同様に 1000 倍の観察結果より $L_{\mathrm{L}}$ を測定し，結果を図 5 に示した． $L_{\mathrm{L}}$ の分布も正規分布則にし たがっており，通処理電により $L_{\mathrm{L}}$ は大きくなる。得られた $L_{\mathrm{L}}$ の平均值より，（2）式を用いて $A_{\mathrm{A}}$ を算出し表 1 に示した。 この結果，通電処理により 2 相界面量が Sample A で約20\%， Sample B で約 $40 \%$ それぞれ増大していた。

\subsubsection{3 相界面の曲率半径}

界面部の観察例を図 6 に示す。これらの観察より，3 相界面 部の曲率半径を測定した結果を図 7 に示す。各曲率半径の分布 は正規分布則にしたがっており，平均值を算出し表 1 に示し た. 曲率半径は通電処理により, 通電前の曲率半径から半分程 度に縮小している。

\section{2 .42 相界面の状態}

図 6 に示す界面部の観察より，通電処理後の試料で 2 相界

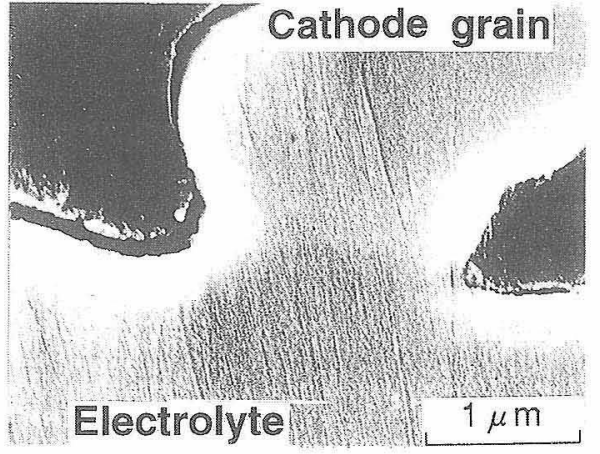

(a) As-sintered

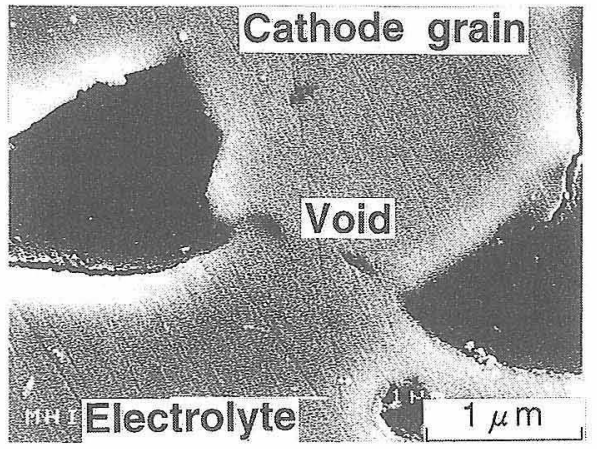

(b) After currentillow treatment

Fig. 6. Scanning electron images of Sample A. (a) As-sintered, (b) after current-flow treatment.

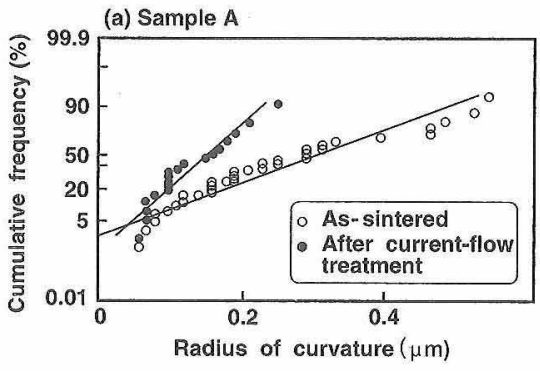

(b) Sample B

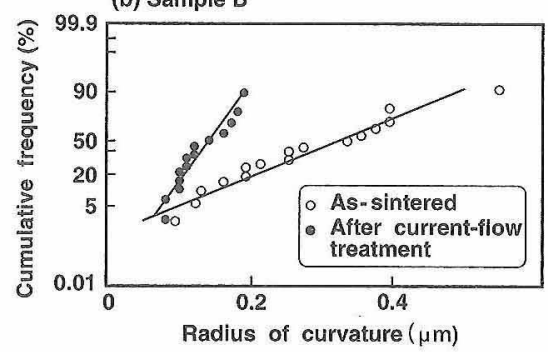

Fig. 7. Changes of the distribution of the radius of curvature at the three phase boundary by the current-flow treatment. (a) Sample A, (b) Sample B.

面にポイドが観察された. ボイドの生成は, 観察試料の約半数 に認められた。

\section{3 通電処理中の酸素還元反応部分の推定}

通電処理中に生じた微構造の変化から, 酸素の還元反応が生 じた領域を推定する。微構造の観察結果は，3 相界面量と 2 相 界面量の増大を示している.すなわち，カソードと電解質の接 触面積が増大しており, 通電処理中にカソードの焼結が進んだ ものと考えられる. 図 3 で観察される変化として, 通電好理 
による反射電子像の黒色部分すなわち気孔部分の減少がある. この現象も，通電処理による焼結の進行を示すものと考えられ る.カソードは $1300^{\circ} \mathrm{C} て ゙$ 電解質に焼結しておう, 測定温度で は安定と考えられるが, 通電時のジュール熱による温度の上昇 等により焼結が進んだものと考えられる. しかし, 通電処理時 に生じた界面量の増大を焼結現象のみで説明すると， 3 相界面 の曲率半径の縮小と矛盾が生じる。焼結が進行すればネック （3相界面）部の曲率半径は増大し，図 7 に示した結果と異な るものと考えられる. 界面量が増加し， 3 相界面の曲率半径が 縮小する現象として, 焼結の進行と同時に 3 相界面にボイド が生成することが考えられる。通電処理中は電解質中を酸素イ オンが移動している。電解質中の酸素イオンの移動は空孔機

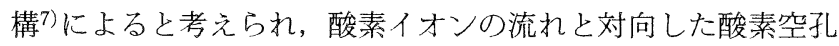
の流れが存在する。酸素イオンは， 3 相界面めるいは 2 相界面 から以下の経路で電解質に入ると考えられる。

（1）酸素イオンが，3相界面近傍から直接電解質に入る.

（2）酸素イオンが， 3 相界面からカソードと電解質界面を 拡散し， 2 相界面から電解質に入る.

（3）酸素イオンが, カソードの結晶構造中を拡散し，2 相 界面から電解質に入る.

(1), (2)の場合には, 酸素イオンの対向流として酸素空孔が 3 相界面に集まり, 酸素空孔の集積であるボイドが形成される可 能性がある。

また，2相界面で観察されたボイドは，(2)，(3)の場合に発 生する可能性がある. 2 相界面で酸素イオンが電解質に入る上 すると, その対向流である酸素空孔が電解質から排出される. この酸素空孔は, カソードのペロブスカイト構造に取り込まれ るか, あるいはカソードと電解質界面を拡散して 3 相界面に 達する。このとき, ペロブスカイト構造中あるいは 3 相界面 への酸素空孔の流れが多くなり, 単位時間当たりに拡散できる 量を超えると酸素空孔が集積しボイドが生成する。このよう に, 通電処理後の 2 相界面で観察されたボイドの生成と 3 相 界面の曲率半径の縮小は, 酸素空孔の集積により生じたと考え られる. 以上の推論でのカソードと電解質界面における, 通電 中の酸素空孔の流れを図 8 に示す。したがって微構造の観察結 果から, 通電処理中の酸素の還元反応は, 2 相界面上 3 相界面 の両方で生じた可能性がある。

\section{4 通電処理による電極性能への影響}

カソードに通電処理を行い過電圧が低下し, 交換電流密度が 増大した。この現象は, 通電中に生じた変化が影響している. 図 4, 図 5 ならびに図 7 に示した通電処理により生じた微構造 变化は, 界面量の増大と 3 相界面部の曲率半径の縮小である。 界面量と交換電流密度の関係を図 9 に示すが，3相界面量が多

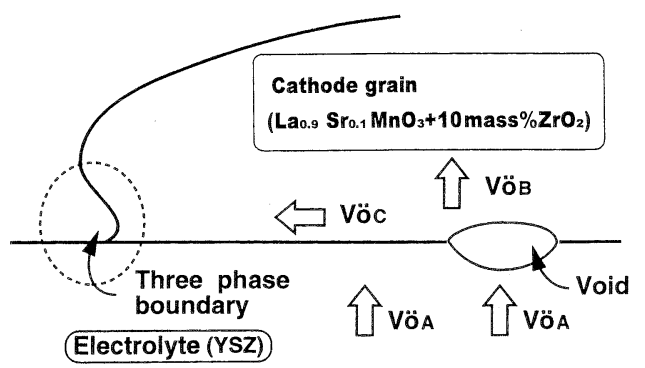

VöA > VöB + Vöc … Void formed VöA $=$ VöB + Vöc $\cdots$ Void unformed

Fig. 8. Schematics of the oxygen vacancy movement at the boundary between the cathode electrode and electrolyte.

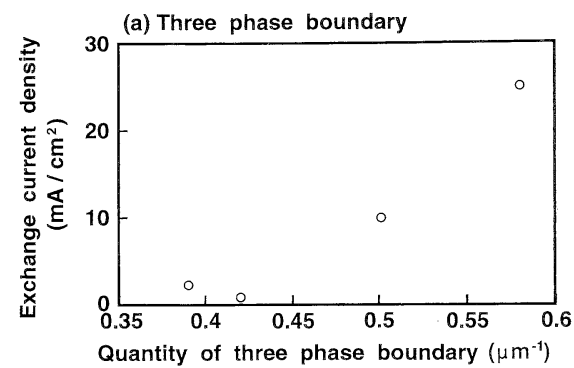

(b) Two phase boundary

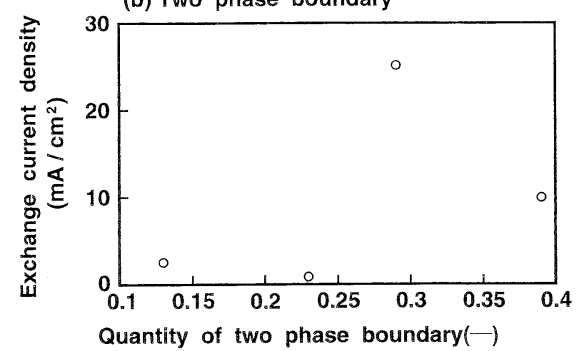

Fig. 9. Relation between the exchange current density and the quantity of the phase boundary. (a) Three phase boundary, (b) two phase boundary.

くなると交換電流密度が増加する傾向が認められる，逆に，2 相界面量上交換電流密度の間には明確な傾向は認められない。 先に示したように 3 相界面で酸素還元反応が生じていた微構 造的な特徵が観察されており，3相界面が主として通電処理中 に酸素還元反応が生じていた領域である可能性が高い。しか し, 通電処理による電極性能の変化は, 交換電流密度が 4 倍か ら28倍の増加を示しており,たかだか $40 \%$ 程度の 3 相界面量 の増加のみでは説明できない。図 7 に示した通電処理による 3 相界面の曲率半径の縮小は, 3 相界面の質的な变化が生じた 可能性を示している. 空孔濃度は曲率半径に反比例することか ら, 小さな曲率半径を持った 3 相界面は空孔濃度が高くなっ て抢り8), 酸素イオンが 3 相界面に入りやすくなっている可能 性があると考えられる. 通電処理により 3 相界面の曲率半径 が半分程度まで縮小したから， 3 相界面の空孔濃度はほほ 2 倍 になっている可能性がある。しかし， 3 相界面の空孔濃度が 2 倍になり, 酸素イオンを取り込む可能性が空孔濃度に比例して 2 倍になったと仮定しても，通電処理による交換電流密度の増 加は十分に説明できない。したがって, 観察した微構造の形態 变化以外の原因が電極性能に影響したと考えられる.

図10に通電処理前後のオージェ電子分光分析法による観察結 果を示す.オージェ電子分光分析法により, 通電処理前後の力 ソードと電解質界面の状態を各 4 点観察し比較したが，界面 部にカソード中の YSZ 粒子が濃縮する傾向は認められなかっ た。図10では，Laに比較して Mnの信号が弱く，Mnの分布 を観察するために感度を高萑察を行った。このため周曲か らの回り込みのオージェ電子を放出しやすい樹脂部分からの信 号が増え，La と Mnの分布が異なってみえる。両観察とも， 写真中央の電解質とカソードが接触した部分は, 樹脂からの信 号はなく, 通電処理前後での状態の比較ができる.

通電処理前の試料では, カソードと電解質の界面は明瞭であ り变質部は認められない。これに対して通電処理後の試料は, 界面部カソード側に Mn の消失した領域が認められる。この 部分は, ボイドが生成している領域と一致して抢り, $\mathrm{Mn}$ の消 失には酸素イオンと酸素空孔の拡散が関係しているものと考え られる。また, Thampi ら ${ }^{9)}$ はn 老電解質中に払散させる 


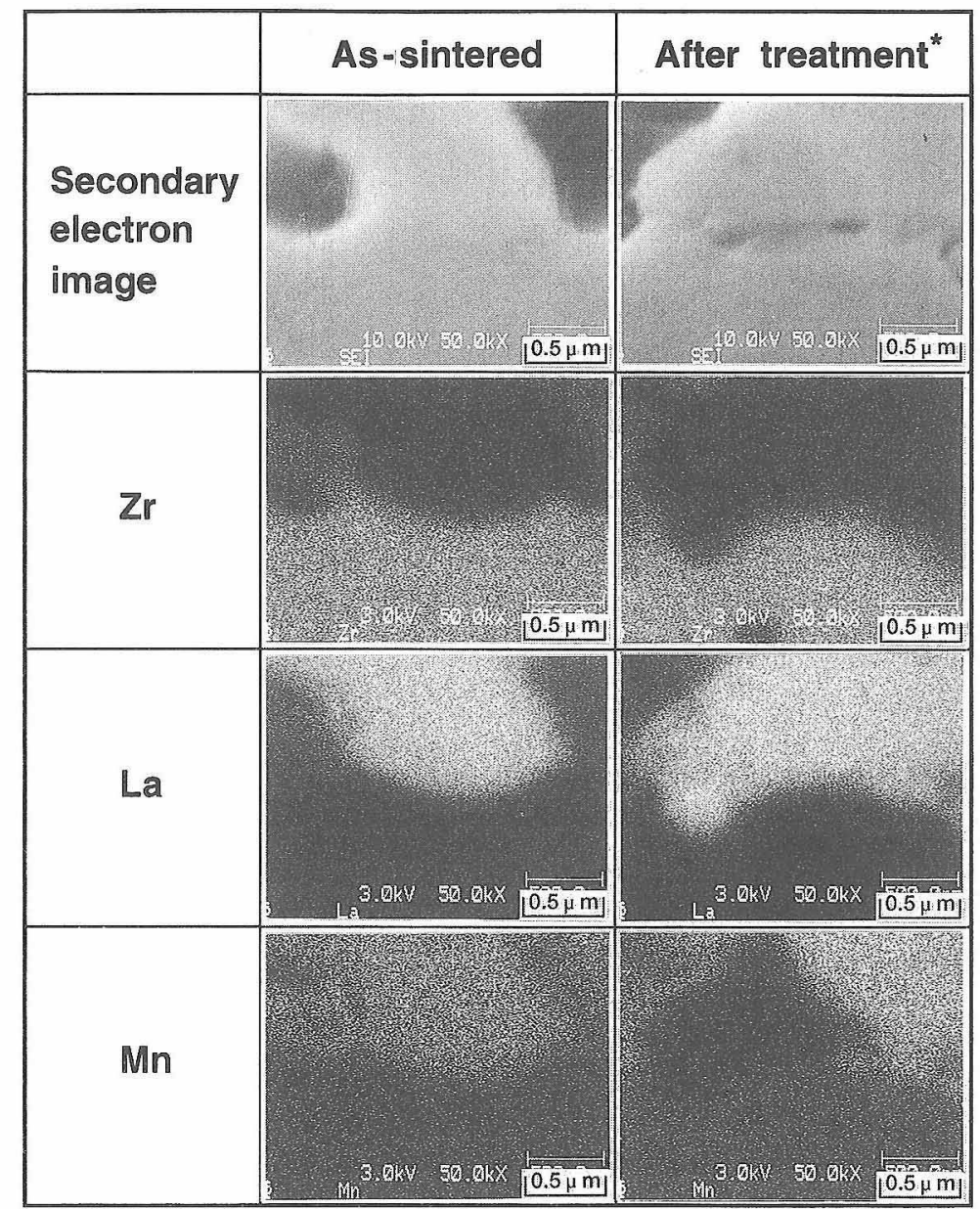

* Current-flow treatment at $0.5 \mathrm{~A} / \mathrm{cm}^{2}$ for $18.5 \mathrm{~h}$ (at 1273k)

Fig. 10. Auger electron spectroscopy images of the Sample B.

と，電極性能が向上することを報告しており，電極部分の Mn が電解質内に拡散し電極性能を改善した可能性がある.

\section{4. 結 言}

微構造の異なるカソードに通電処理を行うことで, 電極特性 が改善され，同時に微構造が変化した，微構造の变化は，(1) 3 相界面量の增大，（2） 2 相界面量の增大，(3) 3 相界面部 の曲率半径の縮小，(4) 2 相界面のボイド生成, である。こ れらの変化は, 通電中の酸素イオン, 酸素空孔が 3 相界面あ るいは 2 相界面と 3 相界面を経由して移動していることを示 唆していると考えられた，更に，交換電流密度と界面量の関係 を検討し，3 相界面量と交換電流密度に依存性が認められ，3 相界面が主たる酸素還元反応領域である可能性を示した。しか し，通電処理による交換電流密度の改善の定量的評価では， 3 相界面量の増加と 3 相界面の曲率半径の変化を考慮しても, 十分に改善の効果を説明できなかった，通電処理前後の界面部 のオージェ電子分光分析による組成分析の結果, カソード側の $\mathrm{Mn}$ が一部消失している部分があり，この $\mathrm{Mn}$ の消失と移動が
交換電流密度の増大に寄与している可能性を指摘した.

\section{文献}

1) N. L. Robertson and J. N. Michaels, J. Electrochem. Soc., 137, 129-35 (1990)

2) J. Mizusaki, H. Tagawa, K. Tuneyoshi and A. Sawada, Proc. 1st Int. Symp. Solid Oxide Fuel Cells, Ed. by S. C. Singhal, Electrochem. Soc., Pennington, NJ (1989) pp. 254-64.

3）高橋武彦, 岩原弘育, 伊藤 勲, 電気化学, 38 , No. 4, 288$93(1970)$.

4）奥山良一, 木田健三, 大田博光, 竹内伸二, 江崎義美, 電池, 討論会予稿集 (1991) pp. 203-04.

5）森 昌史, 山本 融, 伊藤 響, 阿部俊夫, 電力中央研究所 報告. 研究報告, [5], W93019 (1994).

6) R. T. DeHoff and F. N. Rhines, "Quantitative Microscopy," McGraw-Hill (1968) pp. 89-144.

7）例えば, 日本化学会編, 化学総説 “固体の関与する無機反応”, No. 9 (1975) pp. 237-62.

8）例えば，斎藤安俊，斎藤一弥編訳，JME 材料科学“金属酸化 物のノソストイキオメトリーと電気伝導”, 内田老鶴圈 (1987) pp. 77-109.

9) K. R. Thampi, A. J. Mcevoy and J. Van Herle, Proc. 2nd Int. Symp. Ion Mix Conduct. Ceram. (1994) pp. 238-49. 